\title{
BEBERAPA DETERMINAN YANG MEMPENGARUHI KADAR TIMAH HITAM (Pb) DALAM DARAH PEKERJA INDUSTRI PELEBURAN AKI DI PERKAMPUNGAN INDUSTRI KECIL (PIK) DESA KEBASEN KECAMATAN TALANG KABUPATEN TEGAL TAHUN 2016
}

\author{
Nurika Siti Istikomah $^{1)}$, Aris Santjaka ${ }^{2)}$, Zaeni Budiono ${ }^{3)}$ \\ Jurusan Kesehatan Lingkungan, Politeknik Kesehatan Kemenkes Semarang, \\ Jl. Raya Baturaden KM 12 Purwokerto, Jawa Tengah, Indonesia
}

\begin{abstract}
Abstrak
Industri peleburan aki bekas merupakan salah satu industri yang sangat potensial mencemari lingkungan terutama pencemaran udara. Salah satu bahaya kesehatan yang ditimbulkan pada saat proses peleburan berlangsung adanya persebaran partikel debu yang berupa logam $\mathrm{Pb}$ dan gas $\mathrm{SO}_{2}$, paparan debu tersebut dapat menyebabkan meningkatnya kadar Pb dalam darah. Pb merupakan racun yang mempengaruhi kesehatan manusia dan bersifat akumulatif. Penelitian ini bertujuan untuk mengetahui beberapa determinan yang mempengaruhi kadar $\mathrm{Pb}$ dalam darah pekerja peleburan aki. Jenis penelitian ini digunakan observasional dengan pendekatan crosssectional. Responden penelitian sebanyak 11 orang pekerja peleburan aki. Pengumpulan data dilakukan dengan pengukuran kadar Pb di udara, pemeriksaan kadar Pb dalam darah, wawancara, dan observasi responden. Analisis data dengan uji regresi ganda, untuk mengetahui pengaruh masing-masing variabel dengan mengendalikan variabel lainya digunakan uji korelasi parsial. Hasil uji statistik menunjukkan ada hubungan bermakna antara usia, dan masa kerja dengan kadar Pb dalam darah dengan koefisien korelasi sebesar 0,788 dengan $\rho=0,021$. Hasil uji regresi membuktikan bahwa kadar Pb di udara, kebiasaan merokok, usia, dan masa kerja secara bersama-sama mempengaruhi kadar Pb dalam darah pekerja. Saran peneliti berikutnya perlu dikembangkan lebih lanjut dengan jumlah sampel lebih banyak dan dikembangkan dengan metode kohort untuk menemukan sebab yang sebenarnya sehingga upaya pengendalian dapat lebih terarah. Kesehatan pekerja diharapkan lebih diperhatikan dengan melakukan medical check up secara periodik.
\end{abstract}

Kata kunci : Kadar Pb dalam darah, usia, masa kerja

\begin{abstract}
Used batteries smelting industry is one of the potential industries to pollute the environment, especially air pollution. One of the health hazards posed during the melting process is the exposure of dust particles in the form of lead and $\mathrm{SO}_{2}$ gas. The exposure can increase the blood lead levels. Lead is a poison that affects human health and it is accumulative. This study aims to determine some of the determinants that affect the blood levels lead of batteries smelting workers. This research used observational cross- sectional approach. Respondents were 11 workers of used batteries smelting. The data collection is done by measuring the air lead particles, examination of lead levels in the blood, interview, and observation of respondents. The data were analyzed by multiple regression test to determine the effect of each variable towards other variables using partial correlation test. Statistical analysis showed a significant correlation between age and tenure with the blood lead levels with a correlation coefficient of 0.788 with $\rho=0.021$. Regression test results prove that the level of air lead particles, smoking habits, age, and tenure affect the blood lead levels of the workers. Based on the findings, the following research need to be held with more samples and further developed through cohort method to find the real reason so that the effort to control can be more focused. Health of the workers are expected to be more considered by doing medical checkup periodically.
\end{abstract}

Keywords : Blood lead levels, age, tenure

\section{PENDAHULUAN}

Pembangunan industri pada saat ini menyebabkan paparan logam berat diantaranya adalah timbal atau timah hitam atau plumbum $(\mathrm{Pb})$. Mayoritas timah hitam berasal dari pembakaran bahan bakar kendaraan bermotor, emisi industri, dan penggunaan cat bangunan yang mengandung timah hitam. Timah hitam juga dapat mencemari air minum karena

1) Email : nurikasitiistikomah@yahoo.co.id

2) Email : arissantjaka@gmail.com

3) Email : pakzaeni@gmail.com 
adanya kontaminasi dari pipa, solder wire, dan kran air. Timah hitam juga dapat mencemari air minum karena adanya kontaminasi dari pipa, solder wire dan kran air. Logam timah hitam tersebut memiliki potensi dampak negatif terhadap kesehatan manusia, baik jangka pendek maupun jangka panjang.

Pemaparan kronis timah hitam dapat menyebabkan gangguan terhadap kesehatan manusia terutama terhadap sistem hematopoetik, sistem saluran cerna, sistem ekresi, fungsi hati, sistem syaraf terutama menurun nya IQ pada anak-anak, encephalopati, gangguan kardiovaskuler. Timah hitam juga meningkatkan radikal bebas, meningkatkan asupan oksigen secara sistemik, sehingga meningkatkan aktifitas Superoxide Dismutase (SOD) yang dapat menyebabkan stres oksidatif sehingga berakibat pada kerusakan oksidatif sel dalam berbagai jaringan.

Penggunaan Timah hitam kini semakin meluas ke berbagai bidang seperti dalam industri logam, aki, cat, industri bahan pengkilap keramik, bahan insektisida, pada pembangkit listrik tenaga panas, dan pada industri bahan bakar untuk ditambahkan ke dalam bensin sebagai anti knock. Penggunaan timah hitam yang semakin banyak dan meningkat ini justru semakin menambah kemungkinan orang terpajan timah hitam. Bukan hanya para konsumen dari produk yang mengandung timah hitam tersebut, tetapi juga produsennya sendiri bisa terkena timah hitam, terutama pekerjanya. Pajanan tersebut bisa memasuki tubuh manusia melalui banyak cara yaitu melalui saluran pernafasan (inhalasi), saluran pencernaan (oral) dan kulit (dermal).

Kabupaten Tegal merupakan sentra pengrajin logam diantaranya Perkampungan Industri Kecil (PIK) Kebasen, yaitu suatu kawasan pengolahan logam seluas 1,8 hektar, yang berjarak sekitar $1 \mathrm{Km}$ dari pemukiman penduduk, 300 meter dari fasilitas umum, dapat menampung 60 pengrajin skala kecil dengan 120 tungku pengecoran dan PT. Lut Putra Mandiri, terlihat lingkungan kerja yang dipenuhi asap, ventilasi yang sangat minim, tidak terdapat blower atau jendela sebagai jalan sirkulasi udara, cerobong asap yang kecil.

Hasil kajian dampak pembakaran timah di Desa Pesarean Kecamatan Adiwerna Kabupaten Tegal yang dilakukan oleh Kantor Pengendalian Dampak Lingkungan Hidup Kabupaten Tegal pada tahun 2004 diperoleh hasil kadar $\mathrm{Pb}$ udara sebesar $664 \mathrm{mg} / \mathrm{L}$ $(\mathrm{NAB}=350 \mathrm{mg} / \mathrm{L})$. Jika hal ini tidak ada pemantauan terhadap tenaga kerja, dikhawatirkan paparan debu $\mathrm{Pb}$ terus menerus dan terakumulasi akan mengakibatkan gangguan kesehatan pada pekerja.

Survei pendahuluan yang dilakukan pada 21 Februari 2016 diketahui bahwa pekerja mengalami batuk dan hipotensi. Perspektif negatif masyarakat sekitar terhadap kegiatan pembakaran timah yaitu 65 $\%$ responden menghendaki dipindahkan, $65 \%$ responden menghendaki ditutup dan alih profesi, serta 9\% menghendaki dikelola. (Kajian Pengendalian Dampak Lingkungan Hidup, 2005).

$\mathrm{Pb}$ dalam darah juga meningkatkan risiko gangguan fungsi hati pada pekerja peleburan timah hitam kabupaten Tegal (Fidiyatun, dkk, 2013). Rasio prevalensi menunjukkan pekerja yang mempunyai kadar $\mathrm{Pb}$ dalam darah tidak normal atau tinggi ( $>40$ $\mu \mathrm{g} / \mathrm{dL})$ mempunyai risiko 1,783 kali untuk mengalami gangguan fungsi hati dibandingkan pekerja yang mempunyai kadar $\mathrm{Pb}$ dalam darahnya rendah atau normal $(<40 \mu \mathrm{g} / \mathrm{dL})$.

Penelitian ini untuk mengetahui determinan paling berpengaruh terhadap $\mathrm{Pb}$ dalam darah pekerja.

\section{BAHAN DAN METODE}

Jenis penelitian ini adalah penelitian observasional dengan pendekatan cross sectional. Sampel sebanyak 11 orang pekerja yang diamati dengan wawancara dan pengukuran laboratorium. Variabel yang teliti adalah pengaruh kadar $\mathrm{Pb}$ di udara, usia, masa kerja, dan kebiasaan merokok terhadap kadar $\mathrm{Pb}$ dalam darah. Analisis data menggunakan regresi ganda.

\section{III.HASIL DAN PEMBAHASAN}

\section{Kondisi lingkungan fisik tempat kerja}

Indikator faktor lingkungan yang diukur meliputi suhu udara, kelembaban udara, arah angin, kecepatan angin, dan data pengukuran $\mathrm{Pb}$ di udara lokasi penelitian.

\begin{tabular}{llc}
\hline No. & Parameter Terukur & $\begin{array}{c}\text { Rerata Hasil } \\
\text { Pengukuran }\end{array}$ \\
\hline a. & Suhu Udara $\left({ }^{\circ} \mathrm{C}\right)$ & 32,7 \\
b. & Kelembaban Udara $(\%)$ & 64,7 \\
c. & Arah Angin & Selatan \\
d. & Kecepatan Angin $(\mathrm{m} / \mathrm{s})$ & 1,5 \\
\hline
\end{tabular}

Suhu udara sebesar $32,7^{\circ} \mathrm{C}$ termasuk melebihi persyaratan kesehatan lingkungan tempat kerja yaitu sebesar $18-28^{\circ} \mathrm{C}$. Pada suhu tersebut kondisi lingkungan sudah terasa panas. Hasil pengukuran kelembaban udara melebihi yang disyaratkan oleh Permenkes No. 1405 tahun 2002 yaitu sebesar 40$60 \%$.

Sebagai data penunjang penelitian ini maka dilakukan pemeriksaan suhu udara, kelembaban udara, arah angin, dan kecepatan angin. Suhu adalah tingkat panas suatu benda (Tjasjono, 1999). Perubahan suhu mengikuti prinsip termodinamika yaitu ilmu yang mempelajari terjadinya transformasi energi karena perubahan aliran panas dan usaha yang dilakukan. Perpindahan panas atau energi dalam suatu sistem dikenal melalui empat tahap yaitu radiasi, konduksi, konveksi, dan evaporasi. Radiasi adalah suatu transfer energi panas dari suatu permukaan objek ke objek lainnya tanpa mengalami kontak dari kedua objek. Semakin tinggi suhu udara akan semakin mudah untuk menjadi konduktor yang lebih baik dibanding pada suhu yang lebih rendah. Konveksi yaitu perpindahan panas yang disertai 
perpindahan partikel-partikelnya, sehingga massa jenis udara panas lebih ringan, kemudian lingkungan menjadi lebih panas tanpa harus bersentuhan langsung.

Perbedaan suhu secara vertikal akan mengendalikan intensitas turbulensi termis dan selanjutnya mengatur dispersi ke atas dan laju pergantian udara yang lebih bersih dari atas ke bawah (Pepper, 1996). Rerata hasil pengukuran suhu udara di lokasi penelitian adalah $32,7^{\circ} \mathrm{C}$. Besarnya suhu udara di lokasi penelitian dipengaruhi oleh kondisi lokasi yang merupakan areal terbuka sehingga intensitas cahaya matahari langsung mengenai lokasi. Pengambilan data dilakukan pada saat siang hari dimana proses peleburan aki bekas sedang berada di puncak produksi. Suhu udara yang tinggi menyebabkan semakin cepatnya distribusi bahan pencemar $\mathrm{Pb}$ di lokasi penelitian.

Cuaca panas menyebabkan pekerja beraktivitas mengalami evaporasi sebagai hasil metabolisme tubuh dan perubahan kondisi lingkungan, dampaknya tubuh akan mengeluarkan cairan sebagai dampak dari penguapan tersebut. Tubuh akan memberikan respon untuk mengganti energi yang dikeluarkan dengan semakin cepat proses bernafas dan konsumsi air minum yang terpajan debu $\mathrm{Pb}$

Tinggi rendahnya kelembaban relatif dapat menentukan besar kecilnya kandungan bahan pencemar (Hyland, 1989 dalam Tunggul, 2005). Rerata kelembaban udara di Perkampungan Industri Kecil (PIK) Desa Kebasen sebesar 64,7\%. Penelitian ini dilakukan pada saat cuaca panas sehingga memiliki kelembaban yang rendah. Rendahnya kelembaban udara ini karena intensitas cahaya matahari tinggi dan kadar air di udara rendah. Rendahnya kelembaban udara ini akan menyebabkan bahan pencemaran $\mathrm{Pb}$ akan meningkat.

Angin merupakan faktor penting dalam pendistribusian, transportasi, dan dispersi bahan polutan di udara. kecepatan angin dapat menentukan lama waktu perjalanan partikel ke reseptor dan juga laju dispersi bahan polutan atau bahan pencemar. Berdasarkan tabel di atas diketahui rata-rata kecepatan angin di Perkampungan Industri Kecil (PIK) Desa Kebasen adalah 1,5 m/s. Kecepatan angin tidak tinggi karena lokasi penelitian dikelilingi bangunan dan pohon yang dapat menghalangi angin.

\section{Gejala fisik keracunan $\mathrm{Pb}$}

Gejala fisik keracunan $\mathrm{Pb}$ berdasarkan hasil pengamatan dan wawancara dapat digambarkan sebagai berikut :

\section{Gangguan Fisik Keracunan Pb}

- Gangguan Fisik Keracunan Pb

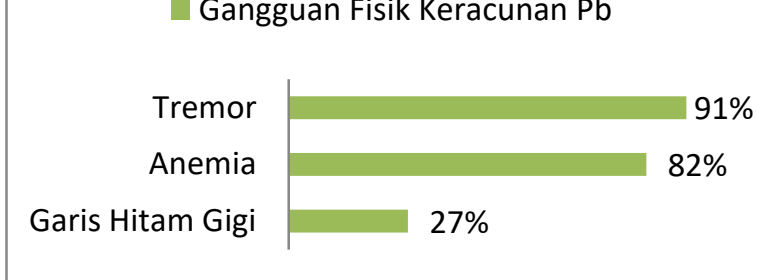

Gangguan fisik yang ditemukan menunjukkan akumulasi $\mathrm{Pb}$ dalam tubuh seperti tremor, anemia, dan gingival lead line. Kadar $\mathrm{Pb}$ dalam darah responden melebihi batas normal yaitu $40 \mu \mathrm{g} / \mathrm{dL}$. Lamanya kerja bertahun-tahun terpajan $\mathrm{Pb}$ menyebabkan tubuh tidak dapat mengabsorbsi $\mathrm{Pb}$ dalam darah sehingga $\mathrm{Pb}$ dalam darah terus-menerus terakumulasi menjadi banyak dan mengendap menjadi racun. Gangguan fisik akibat keracunan $\mathrm{Pb}$ yang terbanyak adalah tremor. Pada tingkat pajanan yang lebih rendah, terjadi penurunan kecepatan bereaksi, memburuknya koordinasi tangan-mata, dan menurunnya kecepatan konduksi syaraf. $\mathrm{Pb}$ merupakan racun syaraf (neuro toxin) yang bersifat kumulatif, destruktif, dan kontinyu pada sistem haemofilik, kardiovaskuler, dan ginjal. Efek pencemaran $\mathrm{Pb}$ dalam darah secara menahun dapat menyebabkan gangguan sistem syaraf yaitu lead encephalopathy (Sudarmaji, h. 134, 2005).

Pajanan timah hitam $(\mathrm{Pb})$ pada pekerja melalui saluran nafas berasal dari debu atau asap kendaraan bermotor di udara. Logam $\mathrm{Pb}$ terhirup masuk ke paru-paru dan akan berikatan dengan darah paru-paru serta diedarkan ke seluruh jaringan organ tubuh. Lebih dari $90 \%$ logam $\mathrm{Pb}$ yang terserap dalam darah berikatan dengan sel darah merah (eritrosit) dan akan menghambat proses pembentukan $\mathrm{Pb}$, sehingga seseorang yang mengabsorbsi $\mathrm{Pb}$ di udara, kandungan $\mathrm{Pb}$ dalam darah akan meningkat dan $\mathrm{Hb}$ akan menurun. (Aditama dalam Wahyu Kurniawan, 2008)

Rerata kadar $\mathrm{Pb}$ dalam darah pekerja PIK Desa Kebasen adalah 89,664 $\mu \mathrm{g} / \mathrm{dL}$. Angka ini merupakan kadar yang tidak normal. Menurut H. Palar (1999) kadar $\mathrm{Pb}$ dalam darah akan mencerminkan profil darah terutama kadar $\mathrm{Hb}$ dan eritrositnya. Kadar $\mathrm{Hb}$ normal berdasarkan Centre for Disease Control and Prevention (CDC) adalah $14 \mathrm{~g} / \%$. Sebanyak 9 orang mengalami anemia dimana kandungan $\mathrm{Hb}$ dibawah kadar normal. Beberapa keluhan pekerja antara lain pusing, lesu, lemas, cepat lelah, nyeri tulang, dan sukar berkonsentrasi.

Salah satu cara deteksi dini pada keracunan timbal dapat dilihat dengan adanya gingival lead line, yaitu pigmen berwarna biru keabu-abuan hingga hitam pada perbatasan gigi dan gusi (Pearce, 2009). Gingival lead line merupakan ciri khas keracunan timbal dan akan timbul jika seseorang memiliki kadar timbal dalam darah $>45 \mu \mathrm{g} / \mathrm{dl}$ selama sekitar 2 bulan, sehingga kadar timbal dalam darah yang tinggi dapat 
dideteksi dengan adanya lead line pada gingiva (WHO, 2002). Gingival lead line akan mengakibatkan gangguan estetis terhadap orang yang menderita (Sudibyo, 1993).

$\mathrm{Pb}$ mempunyai waktu paruh dalam tulang selama 25 tahun. pada tulang ion $\mathrm{Pb}^{2+}$ logam timbal mampu menggantikan keberadaan ion $\mathrm{Ca}^{2+}$ (kalsium) yang terdapat pada jaringan tulang. Pada penelitian ini ditemukan 3 responden yang ditemukan kasus gingival lead line atau garis timah hitam pada tepi gusi yang merupakan salah satu tanda awal dan khas yang dapt dijumpai pada keracunan timbal kronis. Mengonsumsi makanan kalsium akan mengisolasi tubuh dari pajanan $\mathrm{Pb}$ yang baru. Munculnya gingival lead line ini bersifat irreversibel, dimana tidak bisa dikembalikan ke kondisi semula.

\section{Kadar $\mathrm{Pb}$ di udara}

Pengukuran kadar $\mathrm{Pb}$ di udara dilaksanakan selama dua hari. Pengukuran kadar $\mathrm{Pb}$ di udara dilakukan dengan menghisap udara ambien secara gravimetri menggunakan alat Environmental Particulat Air Monitoring (EPAM) Model 5000. Kecepatan aliran diatur sebesar 5 lt/menit selama 40 menit, sehingga diperoleh volume $200 \mathrm{ml}$ sesuai SNI 19-7119.4-2005. Debu di udara ditampung pada kertas saring. Kemudian kertas saring dikirim ke laboratorium Balai Besar Pengendalian Pencemaran Industri Semarang. Metode pemeriksaan $\mathrm{Pb}$ dengan metoda destruksi basah menggunakan spektrofotometer serapan atom.

\begin{tabular}{l}
\hline Parameter Terukur Minimal Maksimal \\
\hline Kadar $\mathrm{Pb}$ di Udara $\mathrm{mg} / \mathrm{m}^{3}$ \\
\hline Rerata kadar $\mathrm{Pb}$ dalam debu di 11 titik lokasi \\
pengambilan sampel adalah $0,0073 \mathrm{mg} / \mathrm{m}^{3}$. Baku \\
mutu yang diperkenankan untuk kadar Pb dalam debu \\
adalah $0,15 \mathrm{mg} / \mathrm{m}^{3}$. Hasil pengukuran paling sedikit \\
sebanyak $0,003 \mathrm{mg} / \mathrm{m}^{3}$ dan paling banyak 0,018 \\
$\mathrm{mg} / \mathrm{m}^{3} . \mathrm{Kadar} \mathrm{Pb}$ ini belum melebihi NAB sebesar \\
$0,15 \mathrm{mg} / \mathrm{m}^{3}$. Hasil pengukuran menunjukkan bahwa \\
kadar $\mathrm{Pb} \mathrm{dalam} \mathrm{debu} \mathrm{udara} \mathrm{di} \mathrm{lokasi} \mathrm{penelitian} \mathrm{masih}$ \\
memenuhi baku mutu. Rendahnya kadar Pb dalam \\
debu udara di Perkampungan Industri Kecil (PIK) \\
Desa Kebasen dikarenakan jumlah aki bekas yang \\
dilebur sedikit dan ada UKM yang tidak melakukan \\
peleburan. Selain itu sirkulasi udara di tempat kerja \\
yang baik dan disekeliling tungku terdapat pohon- \\
pohon yang berfungsi sebagai penyerap emisi. \\
Pajanan Pb udara dengan dosis rendah pada waktu \\
yang lama mengakibatkan terakumulasinya Pb dalam \\
tubuh.
\end{tabular}

\section{Kebiasaan Merokok}

Data kebiasaan merokok didapat dengan cara wawancara terhadap 11 responden pekerja peleburan aki di Perkampungan Industri Kecil (PIK) Desa Kebasen Kec. Talang Kab. Tegal. Keseluruhan responden merupakan perokok. Kebiasaan merokok responden dilihat dari berapa rata-rata rokok yang dihisap per hari dan berapa lama responden menjadi perokok (tahun).

Klasifikasi kebiasaan merokok responden pekerja di Perkampungan Industri Kecil (PIK) Desa Kebasen berdasarkan Indeks Brinkman termasuk pada kelas perokok ringan pada rentan angka 0-200 per tahun. Rerata total kebiasaan merokok responden yaitu 106, angka maksimal 180 dan angka minimalnya adalah 6 .

Menurut Hardiono dalam Indra Cahaya (2005), bahan baku rokok yang diambil dari tembakau, dalam proses penanganannya sering menggunakan pestisida yang juga mengandung bahand dasar timbal $(\mathrm{Pb})$. Responden yang memiliki kebiasaan merokok kadar $\mathrm{Pb}$ meningkatkan jumlah pajanan $\mathrm{Pb}$ baik dari kandungan rokok tersebut maupun dari $\mathrm{Pb}$ udara yang ikut terhisap.

\section{Usia Responden}

Distribusi responden berdasarkan usia responden digambarkan pada grafik sebagai berikut :

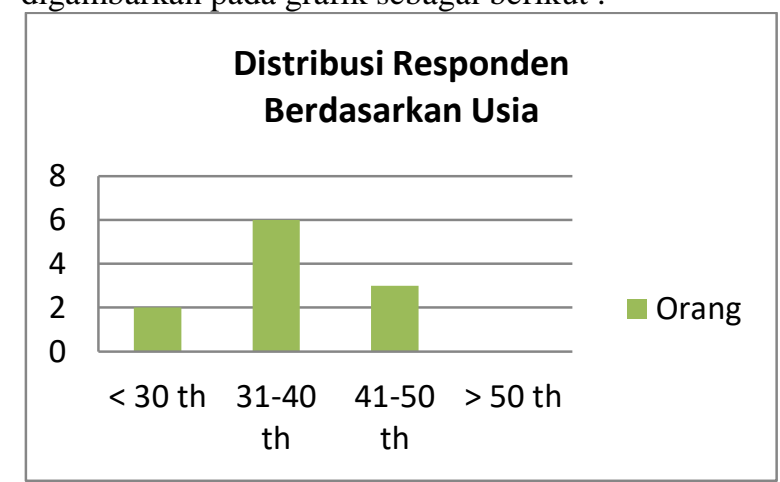

Pajanan $\mathrm{Pb}$ terjadi pada semua kelompok umur. Tenaga kerja di PIK keseluruhan berumur produktif 26-50 tahun, dimana masih dapat bekerja secara maksimal dan kemampuan metabolisme yang baik. Usia muda pada umumnya lebih peka terhadap aktivitas timbal, hal ini berhubungan dengan perkembangan organ dan fungsinya yang belum sempurna. Sedangkan pada usia tua kepekaannya lebih tinggi dari rata-rata orang dewasa, biasanya karena aktivitas enzim biotransformase berkurang dengan bertambahnya umur dan daya tahan organ tertentu berkurang terhadap efek timbal. Semakin tua umur seseorang, akan semakin tinggi pula konsentrasi timbal yang terakumulasi pada jaringan tubuh. Selama hidupnya tenaga kerja terpajan $\mathrm{Pb}$ dari gas buang kendaraan bermotor, jika ditambah dengan pajanan dari kegiatan industri peleburan logam akan semakin tinggi kadar $\mathrm{Pb}$ dalam darahnya.

\section{Masa Kerja Responden}

Distribusi responden berdasarkan usia responden digambarkan pada grafik sebagai berikut : 


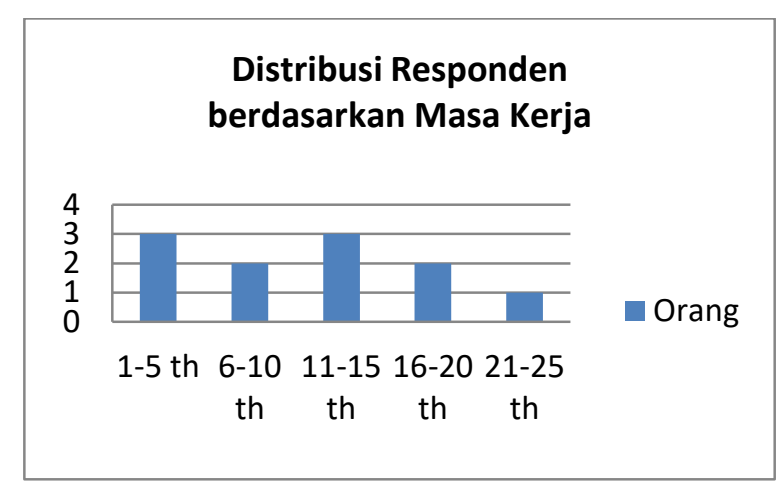

Secara umum lamanya seseorang menjalani suatu pekerjaan akan mempengaruhi sikap dan tindakan dalam bekerja. Semakin lama seseorang mengalami pemajanan bahan pencemar semakin besar risiko yang diterimanya.

\section{Kadar Pb dalam Darah Responden}

Pemeriksaan kadar $\mathrm{Pb}$ dalam darah dilakukan terhadap 11 pekerja peleburan aki di Perkampungan Industri Kecil (PIK) Desa Kebasen Kec. Talang Kab. Tegal. Pengambilan sampel darah dilakukan dengan cara mengambil dari pembuluh vena sebanyak 2,5 cc dengan sampel whole blood. Sampel dikirim ke laboratorium Prodia Tegal pada hari yang sama ketika pengambilan sampel darah.

\begin{tabular}{|c|c|c|}
\hline Parameter Terukur & Minimal & Maksimal \\
\hline $\begin{array}{l}\text { Kadar } \mathrm{Pb} \text { dalam Darah } \\
(\mu \mathrm{g} / \mathrm{dL})\end{array}$ & 54,4 & 121,5 \\
\hline
\end{tabular}

Berdasarkan hasil medical check up dari laboratorium ditunjukkan bahwa keseluruhan responden memiliki kandungan $\mathrm{Pb}$ dalam darah tidak normal yaitu melebihi $>40 \mu \mathrm{g} / \mathrm{dL}$.

Pengaruh kadar Pb di Udara dengan $\mathrm{Pb}$ dalam darah

\begin{tabular}{lccc}
\hline Variabel Independen & $\mathbf{R}$ & $\mathbf{R}^{\mathbf{2}}$ & $\boldsymbol{\rho}$-Value \\
\hline Kadar $\mathrm{Pb}$ & 0,057 & 0,003 & 0,322
\end{tabular}

Hasil uji statistik $\rho$-value lebih besar dari nilai $\alpha=$ 0,05 artinya, tidak ada pengaruh antara kadar $\mathrm{Pb}$ di udara dengan $\mathrm{Pb}$ dalam darah pekerja PIK Kebasen.

Analisis regresi kadar $\mathrm{Pb}$ di udara dengan $\mathrm{Pb}$ dalam darah didapatkan hasil tidak ada pengaruh antara kadar $\mathrm{Pb}$ di udara dengan $\mathrm{Pb}$ dalam darah pekerja PIK Kebasen. $\mathrm{Pb}$ yang masuk ke dalam tubuh responden tidak hanya dari udara yang tercemar, tetapi juga dari makanan yang tercemar $\mathrm{Pb}$ dari debu dan asap pembakaran aki bekas, mengingat sebagian besar makan siang atau makan waktu istirahat di tempat kerja. Makanan yang dimakan juga dikhawatirkan sudah tercemar debu $\mathrm{Pb}$.

Partikel debu residu peleburan aki berukuran lebih dari $>5 \mu$ sehingga akan jatuh sejalan dengan kecepatan gravitasi dan jika terhirup melalui pernafasan biasa akan jatuh pada alat pernafasan atas. Sedangkan partikel yang berukuran lebih kecil akan terbawa angin ke tempat yang lebih jauh dari lingkungan industri sehingga dikhawatirkan masyarakat disekeliling industri juga beresiko kandungan $\mathrm{Pb}$ dalam darahnya tinggi.

Jalur masuk $\mathrm{Pb}$ ke dalam tubuh tidak hanya melalui media udara, namun juga dapat dengan kontak langsung antara kulit manusia dengan debu yang mengandung $\mathrm{Pb}$. Pekerja juga menghirup asap pembakaran yang mengandung $\mathrm{Pb}$ oksida yang tidak tertangkap oleh kertas saring pada saat pengambilan sampel. Partikel $\mathrm{Pb}$ yang berukuran besar akan lebih cepat mengendap di permukaan akibat gaya gravitasi. Pekerja yang tidak memakai pakaian panjang dan sepatu akan lebih mudah kontak dengan permukaan tanah dan terpajan lewat jalur ini.

Kadar $\mathrm{Pb}$ di udara lingkungan kerja sebanyak $0,0073 \mathrm{mg} / \mathrm{m}^{3}$ merupakan konsentrasi yang cukup rendah bila dibandingkan dengan NAB sebesar 0,15 $\mathrm{mg} / \mathrm{m}^{3}$. Penelitian ini sejalan dengan yang dilakukan Ermi Girsang (2008) bahwa tidak ada ada hubungan yang signifikan antara kadar timbal $(\mathrm{Pb})$ di udara ambien terminal antar kota dengan kadar timbal $(\mathrm{Pb})$ dalam darah pegawai di terminal antar kota.

Pengaruh kebiasaan merokok dengan $\mathrm{Pb}$ dalam darah

\begin{tabular}{lccl}
\hline Variabel Independen & $\mathbf{R}$ & $\mathbf{R}^{\mathbf{2}}$ & $\boldsymbol{\rho}$-Value \\
\hline Kebiasaan Merokok & 0,19 & 0,036 & 0,394
\end{tabular}

Hasil uji statistik $\rho$-value lebih besar dari nilai $\alpha=$ 0,05 artinya, tidak ada pengaruh antara kebiasaan merokok pekerja dengan kadar $\mathrm{Pb}$ dalam darah pekerja PIK Kebasen. Pengaruh kebiasaan merokok dengan kadar $\mathrm{Pb}$ dalam darah dapat dilihat pada nilai $\mathrm{R}$ sebesar 0,19 , yang artinya tidak ada pengaruh kebiasaan merokok dengan kadar $\mathrm{Pb}$ dalam darah.

Kebiasaan merokok diduga sesuatu hal yang mempengaruhi tingkat absorpsi $\mathrm{Pb}$ oleh mukosa saluran pernafasan. Merokok dapat menyebabkan perubahan struktur dan fungsi saluran pernafasan dan jaringan paru-paru sehingga suplai oksigen ke jaringan otot akan berkurang yang menyebabkan seseorang lebih cepat lelah. $\mathrm{Pb}$ yang dihasilkan oleh sebatang rokok mengandung $0,5 \mu \mathrm{g}$. 20 batang rokok yang dihisap di dalam darahyna akan mengandung 10 $\mu \mathrm{g} / \mathrm{dL}$.

Berdasarkan tabel di atas bahwa kebiasaan merokok tidak mempengaruhi kadar $\mathrm{Pb}$ dalam darah. Hal ini bisa saja terjadi karena keseluruhan responden merupakan perokok ringan. Perbedaan nilai minimal dengan maksimal yang jauh antar 6 dengan 180 sehingga mengakibatkan kebiasaan merokok memiliki hubungan tidak bermakna secara statistik.

Pengaruh usia dengan $\mathrm{Pb}$ dalam darah

\begin{tabular}{llll}
\hline Variabel Independen & $\mathbf{R}$ & $\mathbf{R}^{\mathbf{2}}$ & $\boldsymbol{\rho}$-Value \\
\hline Usia & 0,438 & 0,192 & 0,016
\end{tabular}

Nilai $\mathrm{R}$ hitung sebesar 0,438 diartikan bahwa ada hubungan antara Usia dengan kadar $\mathrm{Pb}$ dalam darah. Nilai $\mathrm{R}$ hitung < 0,5 maka masuk kategori lemah. 
Pengaruh usia terhadap kadar $\mathrm{Pb}$ dalam darah ditunjukkan oleh nilai R square yaitu sebesar $19,2 \%$. Sisanya sebesar $81,8 \%$ dijelaskan oleh variabel lain yang tidak diteliti.

Analisis pengaruh usia dengan kadar $\mathrm{Pb}$ dalam darah ditunjukkan pada nilai $\mathrm{R}$ sebesar 0,438 yang artinya, ada pengaruh usia dengan kadar $\mathrm{Pb}$ dalma darah. Hasil uji statistik $\rho$-value lebih kecil dari nilai $\alpha=0,05$ artinya, ada pengaruh antara usia dengan kadar $\mathrm{Pb}$ dalam darah pekerja PIK Kebasen.

Pengaruh usia dengan kadar $\mathrm{Pb}$ dalam darah menunjukkan pengaruh yang lemah dan berpola negatif artinya, semakin tua usia semakin berkurang kadar $\mathrm{Pb}$ dalam darahnya. Persamaan garis regresi yang diperoleh dapat menerangkan bahwa usia dapat menjelaskan variabel kadar $\mathrm{Pb}$ dalam darah sebesar $19,2 \%$.

Pajanan $\mathrm{Pb}$ terhadap tenaga kerja tidak hanya berasal dari lingkungan PIK Kebasen saat bekerja, tetapi juga didapatkan dari hasil pembakaran bahan bakar yang mengandung TEL dan $\mathrm{Pb}$ organik itu sendiri. Hasil uji statistik regresi usia dengan $\mathrm{Pb}$ dalam darah $\mathrm{r}$ hitung sebesar 0,438 dengan $\rho$-value sebesar 0,016 berarti pada taraf signifikansi 0,05 ada hubungan yang bermakna, memiliki tingkat pengaruh lemah, dan memiliki arah hubungan positif antara usia dengan kadar $\mathrm{Pb}$ dalam darah. Dapat dimengerti bahwa dengan bertambahnya umur berarti waktu yang dialami responden dalam menghirup udara yang tercemar $\mathrm{Pb}$ dapat meningkatkan kadar $\mathrm{Pb}$ dalam darah.

Rerata usia pekerja di PIK Kebasen 36,5 tahun, paling muda berusia 27 tahun dan paling tua berumur 46 tahun. Usia muda pada umumnya lebih peka terhadap aktivitas $\mathrm{Pb}$, hal tersebut berhubungan erat dengan perkembangan organ dan fungsinya yang belum sempurna. Pada usia tua kepekaannya lebih tinggi, hal tersebut diakibatkan oleh aktivitas enzim biotransformase berkurang dengan bertambahnya umur dan daya tahan organ tertentu berkurang terhadap efek timbal. Semakin tua umur seseorang, akan semakin tinggi jumlah timbal yang terakumulasi pada jaringan tubuh.

Paru-paru umumnya berkembang sampai usia 20 tahun yang secara perlahan akan turun kemampuannya menahan udara sejalan dengan lanjutnya usia karena terjadi penyempitan pada paruparu. Dengan bertambahnya usia berarti waktu ang telah dialami responden dalam menghirup udara yang tercemar semakin panjang.

\section{Pengaruh Masa Kerja dengan Pb dalam Darah}

\begin{tabular}{llll}
\hline Variabel Independen & $\mathbf{R}$ & $\mathbf{R}^{\mathbf{2}}$ & $\boldsymbol{\rho}$-Value \\
\hline Masa Kerja & 0,388 & 0,15 & 0,017
\end{tabular}

Nilai $\mathrm{R}$ hitung sebesar 0,388 diartikan bahwa ada hubungan antara Usia dengan kadar $\mathrm{Pb}$ dalam darah. Nilai R hitung < 0,5 maka masuk kategori lemah. Pengaruh usia terhadap kadar $\mathrm{Pb}$ dalam darah ditunjukkan oleh nilai $\mathrm{R}$ square yaitu sebesar $15 \%$. Sisanya sebesar $85 \%$ dijelaskan oleh variabel yang tidak diteliti. Hasil uji statistik $\rho$-value lebih kecil dari nilai $\alpha=0,05$ artinya, ada pengaruh antara masa kerja dengan $\mathrm{Pb}$ dalam darah pekerja PIK Kebasen.

Pengaruh masa kerja dengan kadar $\mathrm{Pb}$ dalam darah menunjukkan pengaruh yang lemah $(r=0,388)$ dan berpola positif artinya semakin lama masa kerja seseorang bekerja di PIK Kbasen semakin tinggi kadar $\mathrm{Pb}$ dalam darahnya. Persamaan garis regresi yang diperoleh dapat menerangkan bahwa masa kerja dapat menjelaskan variabel kadar $\mathrm{Pb}$ dalam darah sebesar $15 \%$.

Faktor yang mempengaruhi kadar timbal dalam darah tergantung pada lama masa kerja, dimana semakin lama masa kerja seseorang akan berpengaruh terhadap tingginya paparan timbal (Sutomo, 2001). Rerata masa kerja pekerja di PIK Kebasen selama 12,7 tahun, dengan masa kerja minimal 4 tahun dan paling lama 24 tahun. Kadar $\mathrm{Pb}$ dalam darah pekerja dengan masa kerja 4 tahun sebanyak 97,5 $\mu \mathrm{g} / \mathrm{dL}$, sedangkan pekerja dengan masa kerja 24 tahun kadar $\mathrm{Pb}$ darahnya sebesar 121,5 $\mu \mathrm{g} / \mathrm{dL}$.

Hasil uji statistik didapatkan bahwa tingkat signifikan pada derajat kesalahan 5\% $(\alpha=0,05)$ didapatkan nilai $r=0,388$ dan $\rho=0,017$ maka $\rho$ value lebih kecil dari 0,05 yang berarti ada hubungan yang bermakna, memiliki arah hubungan yang positif dan memiliki tingkat keeratan hubungan sedang antara masa kerja dengan kadar $\mathrm{Pb}$ dalam darah pekerja PIK Desa Kebasen, maka dengan demikian lamanya masa kerja responden akan memberikan pengaruh positif pada peningkatan kadar $\mathrm{Pb}$ di dalam darahnya.

Hasil penelitian bahwa masa kerja selama 24 tahun memiliki kadar $\mathrm{Pb}$ dalam darah sebesar 121,5 $\mu \mathrm{g} / \mathrm{dL}$, sedangkan masa kerja selama 5 tahun memiliki kadar $\mathrm{Pb}$ dalam darah sebesar 72,8 $\mu \mathrm{g} / \mathrm{dL}$. menurut Wardayati bahwa faktor yang mempengaruhi kadar timbal dalam darah tergantung dari masa kerja, semakin lama masa kerja semakin banyak terpajan $\mathrm{Pb}$. Selain faktor tersebut pekerjaan tambahan juga mempengaruhi konsentrasi timbal dalam darah, karena semakin sering terpajan timbal $(\mathrm{Pb})$.

Kadar $\mathrm{Pb}$ dalam darah responden sudah memasuki kategori tidak normal. Darmono dalam Irimawa, 2011 menyatakan bahwa keracunan oleh partikel $\mathrm{Pb}$ bersifat kronis, artinya setelah pemaparan oleh senyawa tersebut berlangsung dalam jangka waktu lama atau beberapa tahun kemudian barulah menimbulkan gangguan kesehatan. Beberapa gangguan fisik keracunan $\mathrm{Pb}$ sudah ditemukan pada pekerja PIK Desa Kebasen seperti tremor, anemia, dan ginggival lead line.

Pengaruh Kadar Pb di Udara, Kebiasaan Merokok, Usia, dan Masa Kerja 
Data hasil penelitian dianalisis regresi ganda dengan bantuan software pengolah data. Metode yang digunakan backward dimana variabel yang tidak berpengaruh akan tereleminasi. Koefisian determinasi yang digunakan adalah adjusted $R$ square karena variabel lebih dari satu. Persamaan garis dapat dibuat jika Ho ditolak. (Santjaka, Aris., 2011)

Koefisien regresi ditunjukkan pada nilai $\beta$ untuk variabel usia sebesar $-2,246$ dan nilai $\beta$ untuk variabel masa kerja sebesar 1,947. Regresi ganda yang digunakan untuk menganalisis pengaruh kadar $\mathrm{Pb}$ di udara, kebiasaan merokok, usia, dan masa kerja terhadap kadar $\mathrm{Pb}$ dalam darah secara bersama-sama disajikan pada tabel berikut.

\begin{tabular}{|c|c|c|c|c|}
\hline \multirow[b]{2}{*}{$\begin{array}{l}\text { Variabel } \\
\text { Independen }\end{array}$} & \multicolumn{4}{|c|}{ Adjusted } \\
\hline & $\mathbf{R}$ & $\begin{array}{c}R \\
\text { Square }\end{array}$ & Annova & $\begin{array}{l}\rho- \\
\text { Value }\end{array}$ \\
\hline $\begin{array}{l}\text { Pb Udara, } \\
\text { kebiasaan } \\
\text { merokok, usia, } \\
\text { dan masa kerja }\end{array}$ & 0,788 & 0,526 & 0,021 & 0,021 \\
\hline
\end{tabular}

Hasil uji statistik $\rho$-value lebih kecil dari nilai $\alpha=$ 0,05 artinya, ada pengaruh antara kadar $\mathrm{Pb}$ di udara, kebiasaan merokok, usia, dan masa kerja dengan kadar $\mathrm{Pb}$ dalam darah pekerja PIK Kebasen. Pengaruh kadar $\mathrm{Pb}$ di udara, kebiasaan merokok, usia, dan masa kerja dengan kadar $\mathrm{Pb}$ dalam darah menunjukkan pengaruh yang kuat $(\mathrm{r}=0,788)$ dan berpola positif artinya, semakin tinggi kadar $\mathrm{Pb}$ di udara, semakin banyak kebiasaan merokoknya, banyak usia pekerja dan semakin lama masa kerja seseorang bekerja di PIK Kebasen semakin tinggi kadar $\mathrm{Pb}$ dalam darahnya. Persamaan garis regresi yang diperoleh dapat menerangkan bahwa usia, dan masa kerja kerja dapat menjelaskan variabel kadar $\mathrm{Pb}$ dalam darah sebesar 52,6\% sedangkan, 47,4\% dijelaskan oleh variabel lain yang tidak diamati pada penelitian ini.

Hasil anova digunakan untuk menentukan apakah persamaan garis yang akan dibuat bisa digunakan untuk memprediksi variabel dependen atau tidak. Nilai anova kurang dari nilai $\alpha=0,05$ artinya, persamaan garis dapat dibuat dari persamaan matematik. Persamaan matematik bisa digunakan untuk memperkirakan kondisi variabel dependen (Y) terhadap perubahan yang terjadi pada variabel prediktor $(\mathrm{X})$. Kadar $\mathrm{Pb}$ darah dapat dihitung dengan persamaan garis dengan konstanta sebesar 146,974, koefisien regresi usia sebesar -2,246, dan koefisien regresi masa kerja sebesar 1,947.

Satu set variabel independen ( $\mathrm{Pb}$ di udara, usia, lama kerja,dan kebiasaan) dianalisis secara bersamasama seberapa kuat pengaruhnya terhadap kadar $\mathrm{Pb}$ dalam darah dengan memanfaatkan regresi ganda. Adapun variabel yang berpengaruh terhadap $\mathrm{Pb}$ dalam darah adalah kadar $\mathrm{Pb}$ di udara, usia, lama kerja, dan kebiasaan merokok. Indikator yang digunakan untuk menetukan kuat lemahnya hubungan dinotasikan dengan nilai $\mathrm{R}$ yaitu nilai yang menunjukkan kategori hubungan. Perubahan pada variabel dependen yang disebabkan karena perubahan variabel independen yang lebih dari satu dijelaskan dengan koefisien determinasi (Adjusted $R$ Squre). Persamaan garis regresi ditentukan oleh hasil analisis anova untuk memprediksi variabel "Y" atau respons apa tidak. Besar pengaruh variabel independen dapat diestimasikan dalam bentuk persamaan matematik dengan melihat nilai $\beta$ (beta).

Dalam penelitian ini diperoleh kategori hubungan (R) sebesar 0,788 ini menunjukkan adanya hubungan kuat antara kadar $\mathrm{Pb}$ dalam darah dengan kadar $\mathrm{Pb}$ di udara, usia, lama kerja, dan kebiasaan merokok. Sedangkan Adjusted $R$ Square 52,6 berarti 47,4\% kadar $\mathrm{Pb}$ dalam darah dapat dijelaskan oleh keempat variabel independen. Sedangkan sisanya 47,6\% dijelaskan oleh sebab-sebab lain yang tidak dimasukkan dalam model penelitian.

Hubungan antar variabel yang signifikan adalah umur dan masa kerja, sedangkan yang tidak adalah kadar $\mathrm{Pb}$ di udara dan kebiasaan merokok. Kadar $\mathrm{Pb}$ di udara dan kebiasaan merokok tidak signifikan dipengaruhi oleh sampel yang minim dan homogen, selain itu pajanan $\mathrm{Pb}$ di udara yang bisa saja didapatkan dari lingkungan bukan hanya di PIK Kebasen. Sedangkan umur dan lama kerja seseorang diartikan lama pajanan $\mathrm{Pb}$ terhadap pekerja, sehingga semakin lama kadar $\mathrm{Pb}$ dalam darah semakin besar.

Pembahasan hasil penelitian dari persamaan penelitian dapat dilihat di bawah ini :

Pb dalam darah $=146,974-2,246^{*}$ usia + 1,947*masa kerja

Persamaan diatas dapat digunakan untuk estimasi kadar $\mathrm{Pb}$ dalam darah berdasarkan usia dan masa kerja. Jika dihitung berdasarkan hasil penelitian pada usia dan masa kerja paling minimal yaitu usia 26 tahun dengan masa kerja 4 tahun, kadar $\mathrm{Pb}$ dalam darahnya sebanyak 96,37 $\mu \mathrm{g} / \mathrm{dL}$. Kadar tersebut dikategorikan $\mathrm{C}$ yaitu berlebih dan dapat ditemukan tanda keracunan.

Hasil analisis terlihat bahwa pengaruh usia dan masa kerja memberi pengaruh yang relatif lebih besar dibandingkan kadar $\mathrm{Pb}$ di udara dan kebiasaan merokok. Hal ini terlihat dari besarnya koefisien regresi yang dihasilkan, dimana untuk variabel usia mempunyai koefisien sebesar 0,438; masa kerja sebesar 0,388; kebiasaan merokok sebesar 0,19; dan kadar $\mathrm{Pb}$ di udara sebesar 0,057. Dari hasil ini dapat disimpulkan bahwa kadar $\mathrm{Pb}$ dalam darah mampu dipengaruhi oleh usia dan masa kerja dibandingkan variabel lain.

\section{IV.KESIMPULAN}

Suhu udara di PIK Desa Kebasen sebesar $32,7{ }^{\circ} \mathrm{C}$, kelembaban udara sebesar 64,7 \%, dan kecepatan angin $1,5 \mathrm{~m} / \mathrm{s}$ ke arah selatan. Gangguan fisik keracunan $\mathrm{Pb}$ yang ditemukan adalah tremor, anemia, dan gingival lead line atau garis hitam tepi gusi. Rerata kadar partikel $\mathrm{Pb}$ udara di lingkungan PIK Desa Kebasen sebesar $0,0073 \mathrm{mg} / \mathrm{m}^{3}$, kadar ini tidak 
melebihin NAB yang ditetapkan oleh Permenakertrans No. 13 tahun 2011 yaitu sebesar $0,15 \mathrm{mg} / \mathrm{m}^{3}$. Responden pekerja PIK Desa Kebasen merupakan perokok klasifikasi ringan $(<200)$ dengan angka minimal 6 dan maksimal 180. Masa kerja responden bekerja di PIK Kebasen minmal selama 4, sedangkan paling lama 24 tahun. Usia responden di PIK Kebasen pada kisaran 27 sampai 46 tahun. Rerata kadar $\mathrm{Pb}$ dalam darah pekerja PIK Kebasen sebesar 89,66 $\mu \mathrm{g} / \mathrm{dL}$, kadar ini melebihi NAB normal yaitu sebesar $<40 \mu \mathrm{g} / \mathrm{dL}$. Ada hubungan yang signifikan antara umur dan masa kerja dengan kadar $\mathrm{Pb}$ dalam darah dengan $\rho$-value kurang dari 0,05. Sedangkan variabel kadar $\mathrm{Pb}$ di udara dan kebiasaan merokok tidak signifikan mempengaruhi kadar $\mathrm{Pb}$ dalam darah. Hasil analisis mulitivariat dengan uji regresi ganda menunjukkan bahwa kadar $\mathrm{Pb}$ di udara, kebiasaan merokok, usia, dan masa kerja secara bersama-sama dapat mempengaruhi kadar $\mathrm{Pb}$ dalam darah. Dalam penelitian ini 62,1\% variabel kadar $\mathrm{Pb}$ dalam darah dijelaskan oleh variabel kadar $\mathrm{Pb}$ di udara, kebiasaan merokok, usia, dan masa kerja. Sedangkan sisanya $37,9 \%$ dijelaskan oleh sebabsebab lain.

Saran untuk peneliti lain agar mengganti variabel penelitian, menambah variabel yang di ukur dan metode penelitian dikembangkan lebih lanjut dengan jumlah sampel lebih banyak dan dikembangkan dengan metode kohort untuk menemukan sebab yang sebenarnya sehingga upaya pengendalian dapat lebih terarah.

\section{UCAPAN TERIMA KASIH}

Terima kasih diucapkan kepada Ibu Mela Firdaust, SST. yang telah membantu dalam keberlangsungan penelitian ini.

\section{DAFTAR PUSTAKA}

Agency for Toxic Substances and Disease Registry. 2007. Toxicological Profile for Lead. Atlanta, Georgia : Division of Toxicology and Environmental Medicine/ Applied Toxicology Branch.

Agustriani, Wahyu. 2010. Hubungan antara Lama Masa Kerja dengan Kejadian Gingival Lead Line pada Tukang Parkir di Kota Semarang. Semarang : Skripsi Sarjana Fakultas Kedokteran Universitas Diponegoro.

Badan Standardisasi Nasional. 2009. Pengukuran dengan Metoda Statis Kadar Timah Hitam (Pb) di Udara Tempat Kerja. Jakarta : Badan Standardisasi Nasional.

Clayton, George D. \& Florence E. 1977. Patty's Industrial Hygiene and Toxicology Third Revised Edition. USA : A Wiley-Interscience Publication.
Fidiyatun, dkk. 2013. Hubungan Kadar Pb dalam Darah dengan Kejadian Gangguan Fungsi Hati pada Pekerja Peleburan Timah Hitam di Kabupaten Tegal. Jurnal Kesehatan Lingkungan Indonesia.

Harsono, Didik, dkk. 1995. Pembuatan Alat Penanganan Gas Buang pada Industri Penganganan Aki Bekas. Laporan Penelitian BPI Jawa Tengah.

Hastanto, Sutanto Priyo. 2001. Analisis Data. Jakarta : Fakultas Kesehatan Masyarakat Universitas Indonesia.

Keenan, Kleinfelter. 1999. Kimia untuk Universitas Jilid II. Surabaya : Erlangga.

Kurniawan, Wahyu. 2008. Hubungan Kadar Pb dalam Darah dengan Profil Darah pada Mekanik Kendaraan Bermotor di Kota Pontianak (Thesis). Semarang : Universitas Diponegoro.

Mawardi, Muchtar (dkk). 2013. Hubungan Kadar Timah Hitam $(\mathrm{Pb})$ dengan Kadar Albumin dalam Darah dan Kejadian Anemia (Studi pada Pekerja Peleburan Timah di Perkampungan Industri Kecil (PIK) Kebasen Kab. Tegal. Jurnal Kesehatan Lingkungan Indonesia.

Mukono, H.J. 2005. Toksikologi Lingkungan. Surabaya : Airlangga University Press.

Permenaker No. 13 tahun 2011 tentang Tentang Nilai Ambang Batas Faktor Fisika dan Faktor Kimia di Tempat Kerja.

Permenkes No. 1405 tahun 2002 tentang Kesehatan Lingkungan.

Pudjiastuti, L., dkk. 1998. Kualitas Udara dalam Ruang Hal. 1-9.

Rania, Habal. 2002. Toxicity Lead. Medicine Journal Vol. 3 No. 1.

Riyadina, Woro. 1997. Media Litbangkes Vol. VII No. 03 \& 04/1997. Jakarta : Badan Penelitian dan Pengembangan Kesehatan Depkes RI.

Santjaka, Aris. (2011). Statistik untuk Penelitian Kesehatan 1. Yogyakarta: Nuha Medika.

Santjaka, Aris. 2011. Statistik untuk Penelitian Kesehatan 2. Yogyakarta ; Nuha Medika.

Surip (dkk). 2013. Hubungan antara Kadar Timbal dalam Darah dengan Kadar Hemoglobin pada Wanita Usia Subur di Lingkungan Industri Peleburan Logam Kecamatan Adiwerna Kabupaten Tegal. Jurnal Kesehatan Lingkungan Indonesia. 
Tri Cahyono. 2014. Pedoman Penelitian Proposal Penelitian dan Karya Tulis Ilmiah/ Skripsi (Edisi Revisi Ketiga). Purwokerto : Kementerian Kesehatan Republik Indonesia Politeknik Kesehatan Kemenkes Semarang Jurusan Kesehatan Lingkungan.
Winarso, Hadi. 2011. Faktor-faktor yang Mempengaruhi Kadar $\mathrm{Pb}$ dalam Darah Petugas SPBU di Kota Purwokerto Tahun 2010 (Skripsi). Purwokerto : Prodi DIV Kesehatan Lingkungan Poltekkes Kemenkes Semarang. 